\title{
Examination of the influence of cobalt substitution on the properties of barium titanate ceramics
}

Монамmed TIHTIH - Institute of Ceramics and Polymer Engineering, University of Miskolc, Hungary • medtihtih@gmail.com

IRINA N. SEVOSTIANOVA - Institute of Strength Physics and Materials Science, SB RAS, Tomsk, Russia - sevir@ispms.ru

EMESE KUROVICS - Institute of Ceramics and Polymer Engineering, University of Miskolc, Hungary - fememese@uni-miskolc.hu

TATIANA Yu. SABLINA - Institute of Strength Physics and Materials Science, SB RAS, Tomsk, Russia " sabtat@ispms.ru

SERGEI N. KULKOV - Institute of Strength Physics and Materials Science, SB RAS, Tomsk, Russia - kulkov@ms.tsc.ru

LÁsZLó A. GÖMZE - Institute of Ceramics and Polymer Engineering, University of Miskolc, Hungary, IGREX Engineering Service Ltd • femgomze@uni-miskolc.hu

Érkezett: 2021. 06. 03. - Received: 03. 06. 2021. " https://doi.org/10.14382/epitoanyag-jsbcm.2021.24

\section{Abstract}

Cobalt (Co) doped Barium titanate $\left(\mathrm{BaTiO}_{3}\right)$ powders, with Co concentration $(0,5$ and $10 \mathrm{~mol} \%)$, are synthesized by the sol-gel technique and characterized by Thermogravimetric analysis (TGA), and Differential thermal analysis (DTA), X-Ray diffraction (XRD), Fourier Transform Infrared (FTIR) and scanning electron microscopy (SEM). X-ray diffraction (XRD) patterns of the obtained powders, calcined at a relatively low temperature $\left(1000{ }^{\circ} \mathrm{C} / 3 \mathrm{~h}\right)$, found their crystallization in the pure perovskite structure without the appearance of secondary phases. XRD results reveal that the Co decreases the lattice parameters, the volume of the unit cell and the crystallite size of $\mathrm{BaTiO}_{3}$. The investigations carried out by FT-IR spectroscopy allow the investigation of the substitution procedure behavior associated to the Co incorporation into $\mathrm{BaTiO}_{3}$ lattice. The evolution of the physical parameters as functions of the dopant content have been examined based on XRD and FT-IR results. Furthermore, the morphology and the shape variation of particle size were studied through SEM.

Keywords: barium titanate, co-doping, ferroelectrics, synthesis, XRD, SEM

Kulcsszavak: bárium-titanát, co-dopping, ferroelektromos, szintézis, XRD, SEM

\section{Introduction}

Recently, the research progression in the area of technical ceramics [1]-[7] has drawn great attention [4], [8]-[17]. Perovskite ferroelectric materials $\left(\mathrm{ABO}_{3}\right)$ have had great interest due to the presence of a ferroelectric phase, their relatively simple structure which can allow theoretical interpretations and finally the feasibility of modifying their physical properties by numerous ionic substitutions. In addition, these materials exhibit high-physical performance, dielectric, electro-optical, and electronic properties [18]-[23], which make the materials widely used in various applications in different areas.

Barium titanate $\left(\mathrm{BaTiO}_{3}\right)$ is one of the most important perovskite materials. It is a ferroelectric material, with piezoelectric properties and photorefractive effect. As a solid, it has five phases ranging from low to high temperature: rhombohedral, orthorhombic, tetragonal, cubic and hexagonal crystal structure. Indeed, all of the crystal structures show the ferroelectric effect except cubic structure. It has the appearance of a transparent powder or white crystals. It is soluble in concentrated sulfuric acid perhaps not in water.

Interesting and exotic properties are theoretically expected in doped $\mathrm{BaTiO}_{3}$ like ferromagnetism at room temperature enhanced dielectric properties etc. [24]. Moreover the

Mohammed TIHTIH Is a lecturer in the Sidi Mohamed Ben abdellah University, Morocco, he graduated from Faculty of sciences Dhar El Mahraz, Fez, Morocco, Department of Physics, for the time being, he is a $\mathrm{PhD}$ student in the University of Miskolc, Institute of Ceramics and Polymer Engineering, under supervision of Prof. L. A. Gömze.

Irina N. SEVOSTYANOVA PhD Education: 1987: Tomsk Polytechnic Universityengineer.1993-1996: Institute of Strength Physics and Materials Science of the Russian Academy of Sciences in Tomsk - PhD student. 2001: PhD degree from the Institute of Strength Physics and Materials Science of the Russian Academy of Sciences in Tomsk. Field of research: Structure and mechanical property of porous ceramics based zirconia and alumina.

Emese KUROVICS is graduated in the University of Miskolc. Institute of Ceramics and Polymer Engineering as a material engineer, where she actually continues her study as PhD student under supervision of Prof. L. A. Gömze.

Tatiana Yu. SABLINA

has PhD Education since 1989 at present she is working at the Tomsk State University and Institute of Strength Physics and Materials Science of the Russian Academy of Sciences in Tomsk.

Sergei N. KULKOV is professor of the Tomsk State University and head of Department of Ceramics in the Institute of Strength Physics and Materials Science of the Russian Academy of Science since 1989 His research works are represented in 5 books, more than 150 articles, 18 patents and many International Symposiums and Conferences. At present he is head of department "Theory of Strength and Mechanic of Solids", member of The American Ceramic Society" of "The APMI International" and the DYM AT Society (France).

László A. GÖMZE is establisher and professor of the Department of Ceramics and Silicate Engineering in the University of Miskolc, Hungary. He is author or coauthor of 2 patents, 6 books and more than 300 scientific papers. Recently, he is the chair of the International Organization Board of ic-cmtp6 the $6^{\text {th }}$ International Conference on Competitive Materials and Technological Processes and ecsiliconf2 the $2^{\text {nd }}$ European Conference on Silicon and Silica Based Materials.

synthesis technique also influences the level of doping and physical properties. Based on this fact, several studies are made adopting various synthesis methods such as solid state ceramic technique, laser ablation, sol-gel and chemical routes etc. [25]-[27]. In response to these reports, various types of doping have been attempted for $\mathrm{BaTiO}_{3}$ including $\mathrm{Fe}, \mathrm{Mn}$, $\mathrm{Co}$ etc. [24]-[28].

In the present paper, Co-doped $\mathrm{BaTiO}_{3}$ (BTCox) ceramics, with $\mathrm{x}=(0,5$ and $10 \%)$ were prepared using the sol-gel technique, the choice of this method of processing was based on its various advantages, low processing temperature, high purity, homogeneity and an excellent control of the stoichiometry of the products [29]. We have investigated the phase and structural properties of the prepared samples 
using X-ray diffraction (XRD), Fourier Transform Infrared (FT-IR) spectrometer and Scanning Electronic Microscopy (SEM). Experimental results are analyzed and then discussed as function of the doping concentration and compare the obtained values to those of the literature.

\section{Experimental methods}

\subsection{Materials and synthesis method}

Crystalline powders BTCox were synthesized and obtained using sol-gel method [30] through the destabilization of colloidal solution (DCS). This process provides numerous advantages such as an excellent control of the stoichiometry and a good homogeneity of the powders in spite of crystallization at relatively low temperature [8], [10], [29].

The powders were prepared using barium acetate trihydrate $\left(\mathrm{Ba}\left(\mathrm{CH}_{3} \mathrm{COO}\right)_{2}, 3 \mathrm{H}_{2} \mathrm{O}\right)(99.9 \%$ purity), titanium isopropropoxide $\mathrm{Ti}\left[\mathrm{OCH}\left(\mathrm{CH}_{3}\right)_{2}\right]_{4}$ (97\% purity) and Cobalt acetate $\mathrm{Co}\left(\mathrm{CH}_{3} \mathrm{CO}_{2}\right)_{2} \cdot 4 \mathrm{H}_{2} \mathrm{O}(99.9 \%$ purity) as precursors, lactic acid $\left(\mathrm{CH}_{3} \mathrm{CH}(\mathrm{OH}) \mathrm{COOH}\right)$ as peptizing agent and distilled water as solvent. The different steps relating to the preparation of BTCox powders are shown schematically in the flowchart in Fig. 1. A white sol with adequate proportions was obtained, which was dried in an oven at $80^{\circ} \mathrm{C}$ for $72 \mathrm{~h}$ to obtain a dry gel. The raw powders, after grinding, were calcined in air in a programmable oven at the temperature of $1000^{\circ} \mathrm{C}$ for $3 \mathrm{~h}$.

The samples in pellet shapes were obtained by pressure with an uniaxial pressure equal to 10 tonnes $/ \mathrm{cm}^{2}$. Then, the pellets were sintered $1200{ }^{\circ} \mathrm{C}$ for $6 \mathrm{~h}$ reached with a heating rate $5^{\circ} \mathrm{C} / \mathrm{min}$.

\subsection{Characterization}

Thermal study using Thermogravimetric analysis (TGA), and Differential thermal analysis (DTA) were performed on the sample BTCo15. The crystallinity and phases of the ceramic powders were examined using X-ray diffraction. The powder X-ray pattern was recorded for all samples with various cobalt concentrations by using an $\mathrm{X}$-ray diffractometer equipped with [XPERT-PRO diffractometer with $\mathrm{Cu}-\mathrm{Ka}$ radiation $(\lambda=1.5405980 \AA)$ ]. XRD spectrum was recorded in the $2 \theta$ range of 20 to $80^{\circ}$. The morphology of the ceramic powders was characterized by Scanning electron microscopy (SEM). Moreover, the functional groups in powders were detected by using of a Bruker-Tensor 27 spectrophotometer FT-IR spectroscopy in the wave number range $450-4000 \mathrm{~cm}^{-1}$.

\section{Results and discussion}

\subsection{Thermal analysis}

Fig. 2 shows the thermal analysis (TGA and DTA) of the sample $15 \%$ doped $\mathrm{BaTiO}_{3}$, performed in air up to $1200{ }^{\circ} \mathrm{C}$ with a temperature rate $5^{\circ} \mathrm{C} / \mathrm{min}$. The TGA curve reveals three steps of decomposition (corresponding to an overall mass loss of approximately $28 \mathrm{mg}$ ). The first step $\left(33-320^{\circ} \mathrm{C}\right)$, represents a weight loss which attributed to the elimination of water and excess lactic acid. This mass loss is accompanied by an endothermic peak in the DTA curve. The second stage $\left(320-631^{\circ} \mathrm{C}\right)$, represents a progressive mass loss, accompanied by several peaks endothermic and the other exothermic peaks in the DTA curve which can be attributed to the decomposition of the organic matter and the elimination of $\mathrm{CO}_{2}$. In this temperature range, rearrangements of chemical bonds in the gel occur and the gel is converted to polymers [31]. The last stage of mass loss located in the range of $\left(631-1000^{\circ} \mathrm{C}\right)$ was detected, accompanied by an endothermic peak in the DTA curve, which is attributed to the decomposition of organic polymers and the formation of inorganic substances (the starting formation of BTCo0.15). No reaction or mass loss was noticed above $1000^{\circ} \mathrm{C}$, showing complete crystallization of the ceramic powders. This relatively low temperature compared to other reported from other works using different synthetic techniques [32] is due to the sol gel preparation method [8], [30].

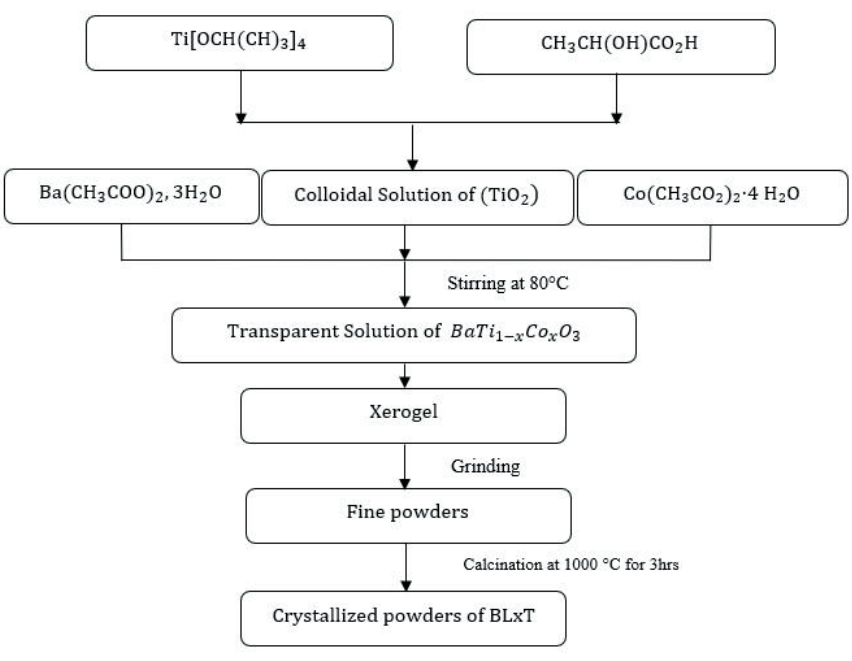

Fig. 1 Flow chart of the sol-gel processing of ( $x=0,0.05$ and 0.1) powder ceramics 1. ábra $A(x=0,0.05$ és 0.1) kerámia porok szol-gél eljárásának folyamata

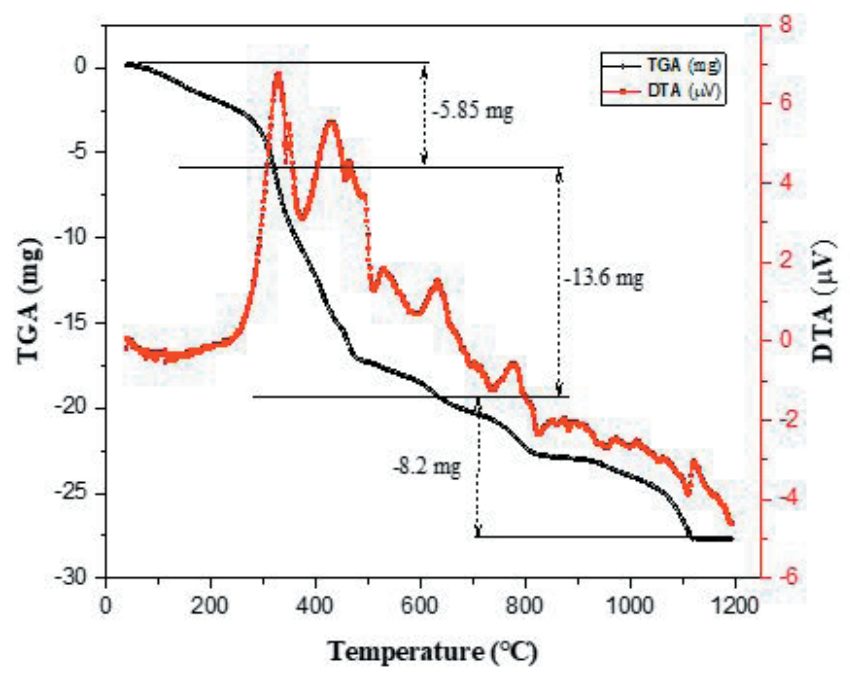

Fig. 2 TG/DTA curves of the (ceramic sample

2. ábra A (kerámiaminta TG/DTA görbéi

\subsection{Structural study}

XRD patterns of the as-prepared powders were investigated, and they are reported as function of the Cobalt concentrations in Fig. 3. It shows that the BTCo crystallize in the perovskite phase without any secondary phase. The peaks are indexed as 
the respective planes on the basis of JCPDS cards. Phan et al.[33] prepared BTCo usnig classical solid state reaction method, after annealing at $1300{ }^{\circ} \mathrm{C}-4 \mathrm{~h}$, but with the presence of the secondary phases. The diffractograms reveal well-resolved peaks, which are a clear indication of the good particles's crystallinity. These peaks are assigned in pure sample, i.e., $\mathrm{x}=0 \%$ to the perovskite structure with the tetragonal phase, which exists throughout the whole concentration ranges. This is supported by the presence of well resolved (002)-(200) doublet peaks around $2 \theta$ of $44-46^{\circ}$ on the diffractogram.

The lattice parameters ( $a$ and $c$ ) were determined from XRD data analysis considering tetragonal phase with an accuracy of $\pm 0.002 \AA$ using the following relations;

$\frac{1}{d^{2}}=\frac{h^{2}+k^{2}}{a^{2}}+\frac{l^{2}}{c^{2}}$

Where a is the lattice constant, $\mathrm{d}$ is interplanar spacing and (hkl) are Miller indices.

The fitted and calculated parameters are given in Table 1. The values of lattice constants ( $\mathrm{a}$ and $\mathrm{c}$ ) are given in Table 1 and were found that the lattice constant $a$ increase while $c$ decreases with Co concentration. Lattice parameters of pure the $\mathrm{BaTiO}_{3}$ sample are in good agreement with reported values $\mathrm{a}=\mathrm{b}=$ $3.988 \AA$ and $c=4.026 \AA\left(\alpha=\beta=\gamma=90^{\circ}\right)$ [33]. Moreover, the decrease in lattice parameters can be attributed to $\mathrm{Co}^{2+}$ ions $(0.58 \AA)$ replacing the $\mathrm{Ti}^{4+}(0.605 \AA)$, having higher ionic radii.

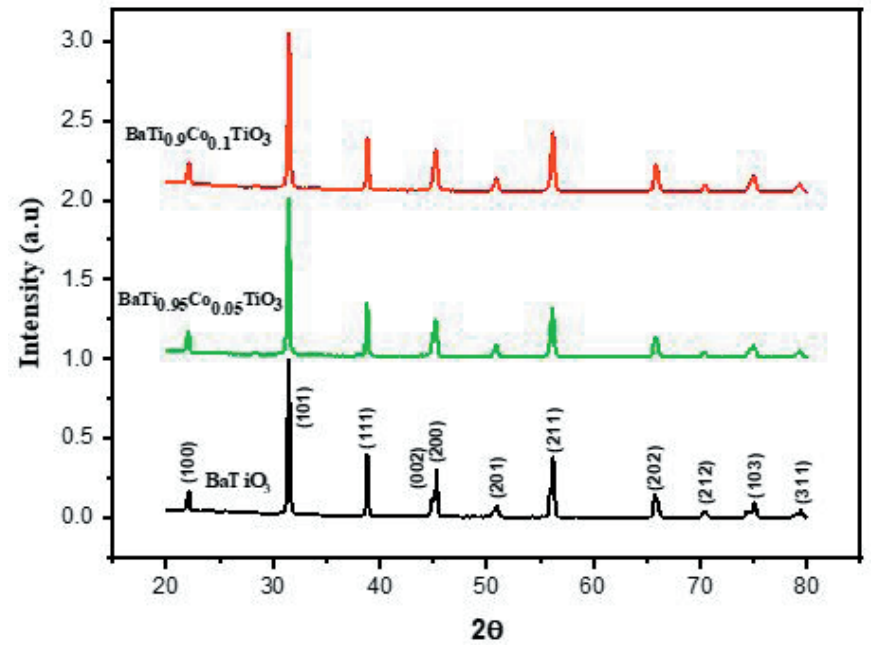

Fig. $3 \mathrm{XRD}$ patterns of Co-doped $\mathrm{BaTiO}_{3}$ powder samples calcined at $1000^{\circ} \mathrm{C}$ for $3 \mathrm{~h}$ 3. ábra $\mathrm{Az} 1000{ }^{\circ} \mathrm{C}$-on 3 órán át kalcinált Co-adalékolt $\mathrm{BaTiO}_{3}$ porminták XRD mintája

\begin{tabular}{lccccccc}
\multicolumn{1}{c}{ Sample } & \multicolumn{7}{c}{ Lattice parameters } \\
& $\mathbf{a}(\AA)$ & $\mathbf{c}(\AA)$ & $\mathbf{V}$ & $\begin{array}{c}\text { Tetrago- } \\
\text { nality }\end{array}$ & $\begin{array}{c}\text { Crystal- } \\
\text { lite size } \\
(\mathbf{n m})\end{array}$ & $\begin{array}{c}\text { Lattice } \\
\text { strain } \\
\left(\times 10^{-3}\right)\end{array}$ \\
\hline $\mathrm{BaTi}_{3}$ & 3.9917 & 4.0247 & 64.1304 & 1.0082 & 42.2725 & 1.38 \\
\hline $\mathrm{BaTi}_{0.95} \mathbf{C o}_{0.05} \mathbf{0}_{3}$ & 3.9945 & 4.0146 & 64.0594 & 1.0050 & 56.3634 & 2.87 \\
\hline $\mathbf{B a T i}_{0.9} \mathbf{C o}_{0.1} \mathbf{0}_{3}$ & 3.9948 & 4.0113 & 64.0136 & 1.0041 & 59.0017 & 2.56
\end{tabular}

Table 1. Lattice parameters, tetragonality, unit cell volume (V), Lattice strain and Crystallite size of Co-doped $\mathrm{BaTiO}_{3}$

1. táblázat A Co-adalékolt $\mathrm{BaTiO}_{3}$ rácsparaméterei, tetragonitása, egységnyi térfogata $(V)$, rácsfeszitése és és kristálymérete
The unit cell volume $(\mathrm{V})$ is known to be most basic characteristic of the solid-state structure and the values of the unit cell volume are given in Table 1. The unit cell volume decreases as Co concentration increases. The decrease in unit cell volume can be attributed to changes in the crystal structure.

Scherrer formula takes into account only the influence of crystallite size on the XRD peak broadening, however, it doesn't provide anything about the sample's microstructures of the lattice i.e., regarding the intrinsic strain, which gets developed in the nanocrystals due to the grain boundary, point defect, stacking faults and triple junction [34]. Many approaches exist, such as Warren-Averbach and Williamsons Hall method, etc., which takes into account the effect of the strain induced XRD peak broadening and can be used to calculate the intrinsic strain along with the particle size. Among these approaches, Williamson-Hall (W-H) method is a very simple and The Williamson-Hall $(\mathrm{W}-\mathrm{H})$ approach is a simple and straightforward one. [34], [35].

The crystallite size and micro-strain was calculated using Williamson-Hall (W-H) plot which explains $\mathrm{x}$-ray diffraction peak broadening [36].

$\beta=\beta_{\text {size }}+\beta_{\text {strain }}$

$\beta=\frac{0.94 \lambda}{D \cos \theta}+4 \varepsilon \tan \theta$

Where, $\beta$ is the full width of half maximum, $\varepsilon$ is the strain, and $\mathrm{D}$ is the crystallite size. Figures $4(a),(b)$ and $(c)$ show the linear plots, the intercepts and the slopes pointing out the crystallite size, as well as the strain of the prepared plotted samples as plotted by Williamson-Hall method. The crystallite size and the strain of single-phase samples are shown in Table 1. The nature of the strain formed was determined by the nature of the slope, that is, with a positive slope indicating a tensile strain and the negative slope indicating a compressive strain [37].

The results revealed that all the samples had a positive slope and were subjected to tensile strain. The strain values of BTCo0.05 compound was found to be higher than the value of the other samples (Pure BaTiO3 and BTCo0.1). The higher value of lattice strain induced in the BTCo0.05 sample is considered due to the creation of oxygen vacancies [38]. Table 1 illustrates the obtained crystallite size and the deviation of strain values BTCox ( $\mathrm{x}=0,5$ and $10 \%)$ samples. In addition, the crystallite size was found in the range of 42.27-59 nm (from W- H plot).

\subsection{Morphological investigation}

Fig. 5 shows the evolution of the morphology and grain size of the $\mathrm{BaTi}_{1-\mathrm{x}} \mathrm{Co}_{\mathrm{x}} \mathrm{O}_{3}(\mathrm{x}=0,0.05$ and 0.1$)$ powders as a function of the cobalt concentrations. Fig. $5 a$ shows that the microstructure is completely anarchic, this is due to the shape of the precursors which have not yet reacted with each other, while the SEM image of the BTCo0.05 powder (Fig. 5b) we notice the start of the incorporation of the precursors together, which is in good agreement with the results of the previous characterizations. Concerning Fig. 5c, we obtained a fine microstructure of average size less than $1 \mu \mathrm{m}$, homogeneous and of regular and well-defined shape, which indicates that the powder crystallizes in the perovskite phase without the presence of impurities. 
a)

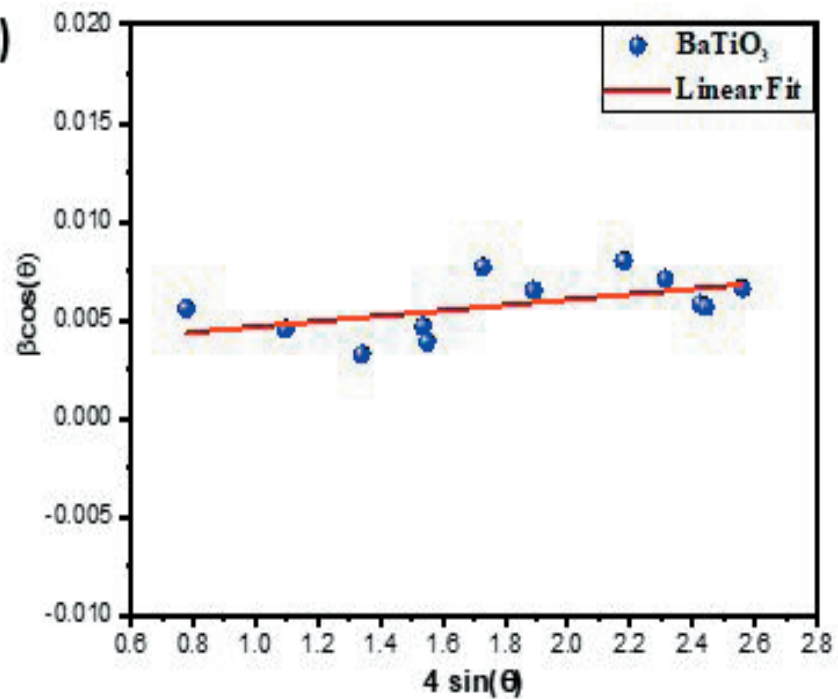

b)

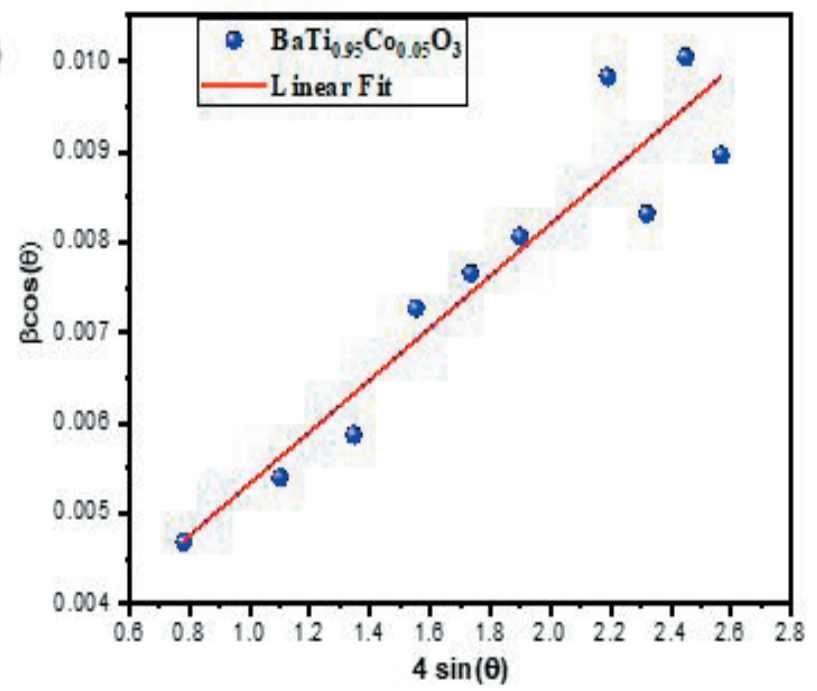

c)

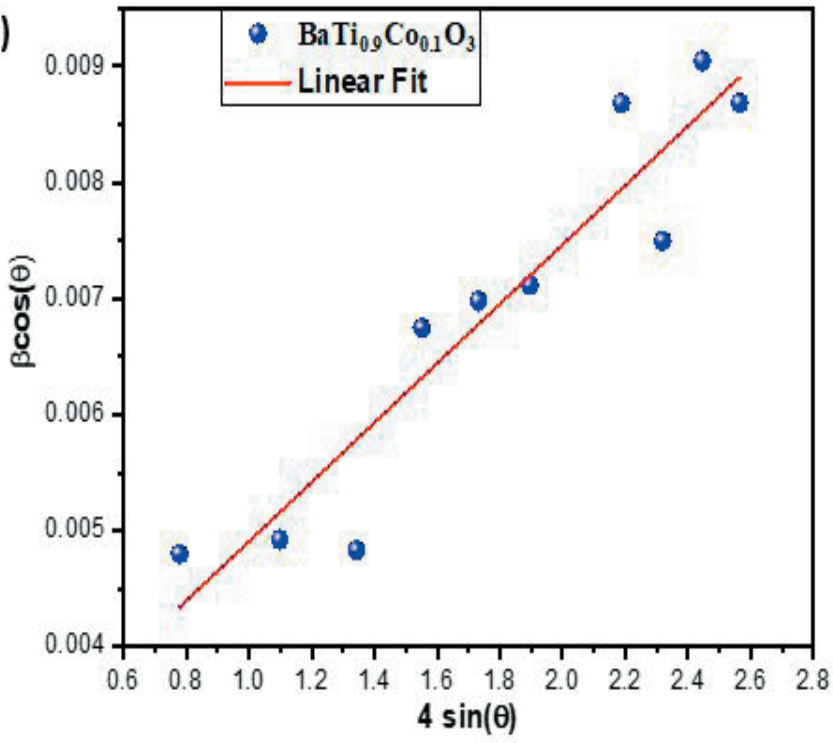

Fig. 4 Williamson-Hall plot of pure and Co doped $\mathrm{BaTiO}_{3}$ samples

4. ábra A tiszta és a Co adalékolt $\mathrm{BaTiO}_{3}$ minták Williamson - Hall diagramja
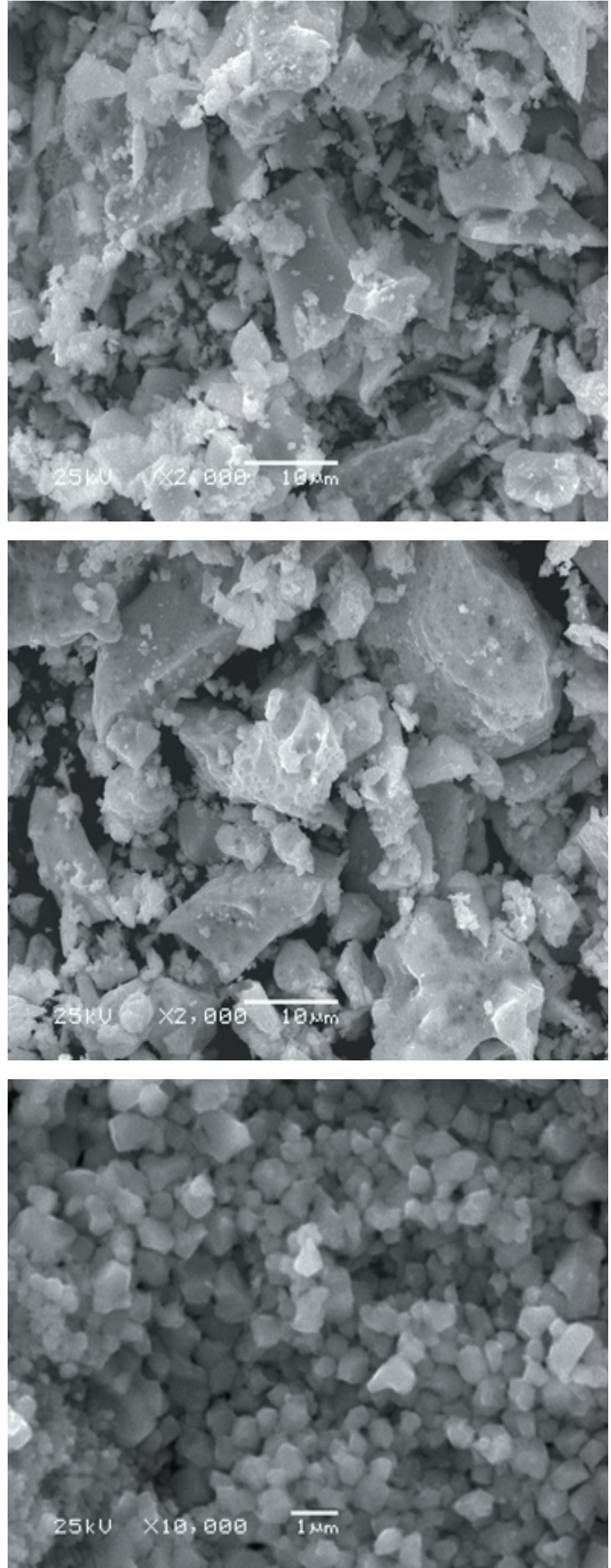

Fig. 5 Morphology images of pure and Co-doped $\mathrm{BaTiO}_{3}$ samples. a) $\mathrm{BaTiO}_{3}$, b) $\left.\mathrm{BaTi}_{0.95} \mathrm{Co}_{0.05} \mathrm{O}_{3}, \mathrm{c}\right) \mathrm{BaTi}_{0.9} \mathrm{Co}_{0.1} \mathrm{O}_{3}$

5. ábra A tiszta és a Co adalékolt $\mathrm{BaTiO}_{3}$ minták mikroszerkezete. a) $\mathrm{BaTiO}_{3}, b$ ) $\left.\mathrm{BaTi}_{0.95} \mathrm{Co}_{0.05} \mathrm{O}_{3}, \mathrm{c}\right) \mathrm{BaTi}_{0.9} \mathrm{Co}_{0.1} \mathrm{O}_{3}$ 


\subsection{FT-IR study}

IR spectra of the as prepared (BTCox) powders, heat treated at $1000{ }^{\circ} \mathrm{C}$ for $3 \mathrm{~h}$, were recorded in a wavelength range of $400 \mathrm{~cm}^{-1}$ to $4000 \mathrm{~cm}^{-1}$. Indeed, the above XRD results is supported by FTIR spectra, as shown in Fig. 6. The peak of absorption at $990 \mathrm{~cm}^{-1}$ attributed to the vibration of the Ti-OR bond [39] dimens slightly in intensity and is transformed into a single band indicating the disappearance of the alkoxide groups. The characteristic absorption at the range of $1455 \mathrm{~cm}^{-1}$ to $1457 \mathrm{~cm}^{-1}$ are assigned to the stretching vibrations of carboxylate as there is a small amount of $\mathrm{BaCO}_{3}$ [40]. In addition, Indeed, we can always observe the appearance of a single absorption bands at around 493, 480 and $490 \mathrm{~cm}^{-1}$ respectively, which can be assigned to the stretching and bending vibrations of the Ti-O bond in $\left[\mathrm{TiO}_{6}\right]^{2-}$ octahedron. The obtained results are therefore in good agreement with those of X-ray diffraction.

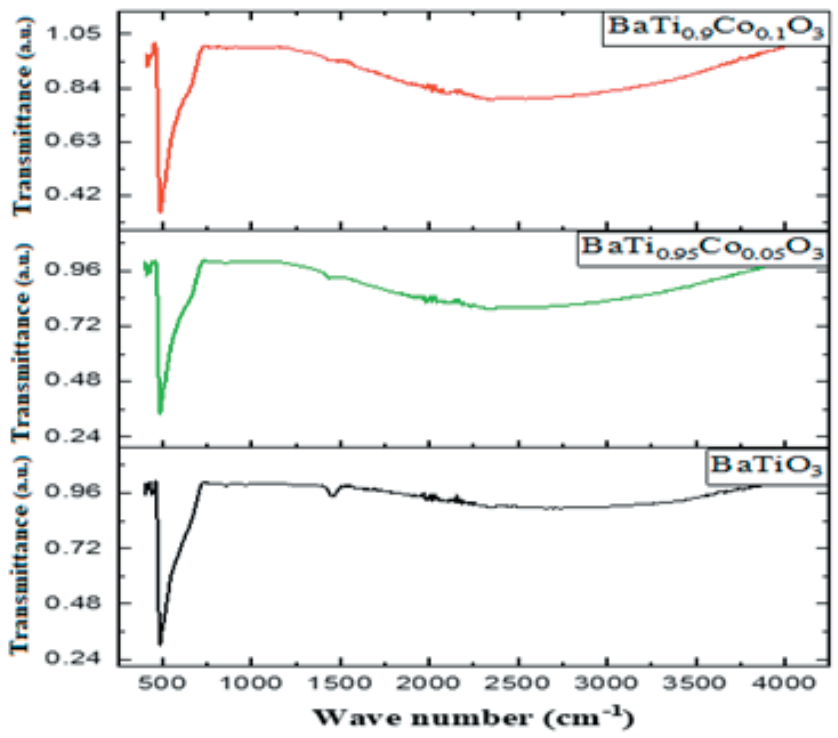

Fig. 6 FT-IR spectra of $\mathrm{BaTi}_{1-x} \mathrm{Co}_{x} \mathrm{TiO}_{3}(x=0,5$ and 10\%) ceramics calcined at 1000 ${ }^{\circ} \mathrm{C} / 4 \mathrm{~h}$

6. ábra $\mathrm{Az} 1000{ }^{\circ} \mathrm{C}$-on 4 óra alatt kalcinált $\mathrm{BaTi}_{1-x} \mathrm{Co}_{x} \mathrm{TiO}_{3}(x=0,5$ és 10\%) kerámiák FT-IR spektrumai

\section{Conclusions}

Cobalt doped barium titanate powders (BTCo) ceramics, with Co contents $(0,5$, and $10 \mathrm{~mol} \%)$, were successfully synthesized by the sol-gel method and characterized by X-Ray diffraction (XRD), scanning electron microscopy (SEM) and FT-IR spectroscopy. XRD results show that the cobalt diminishes the lattice tetragonality of $\mathrm{BaTiO}_{3}$. The XRD pattern confirms that the successful formation of the singlephase (tetragonal) perovskite structure of the all presented ceramic samples. Moreover, the corresponding XRD spectra are exempt of any extra secondary phase indicating a complete incorporation of $\mathrm{Co}^{2+}$ in the $\mathrm{BaTiO}_{3}$ structure then confirmed by FT-IR analysis. The line broadening of $\mathrm{BaTiO}_{3}$ is attributed to small lattice strain and crystallite size. This broadening was examined by $\mathrm{W}-\mathrm{H}$ plot and size-strain plot. According to SEM characterizations, BTCo ceramics were well synthesized, and particle size decreases as dopant concentration increase. In addition, the presented powders samples are relatively homogeneous, consisting of regularly oriented grains in the form of anarchic for $0 \%$ and $5 \%$ of Co and spherical for $10 \% \mathrm{Co}$ doped $\mathrm{BaTiO}_{3}$. For further understanding more samples with mediate composition will be prepare and studied for structural and physical properties.

\section{Acknowledgments}

The described article was carried out as part of the EFOP3.6.1-16-00011 "Younger and Renewing University -Innovative Knowledge City - institutional development of the University of Miskolc aiming at intelligent specialisation" project implemented in the framework of the Széchenyi 2020 program. The work was performed according to the Government research assignment for ISPMS SB RAS, project FWRW-20210005 .

\section{References}

[1] Gömze, L. A., Kulkov, S. N., Kurovics, E., Buyakov, A. S., Buyakova, S. P., Buzimov, A. Y., Géber, R., Grigoriev, M. V., Kocserha, I., Kulkov, A. S., Sablina, T. Yu., Savchenko, N. L., Sevostyanova, I. N., Simon, A. (2018) Investigation of mineralogical composition and technological properties of conventional brick clays, Építőanyag - JSBCM, Vol. 70, No. 1, 8-12. p. https://doi.org/10.14382/epitoanyag-jsbcm.2018.2

[2] Kurovics, E., Kotova, O. B., Gömze, L. A., Shushkov, D. A., Ignatiev, G. V., Sitnikov, P. A., Ryabkov, Y. I., Vaseneva, I. N., Gömze, L. N. (2019) Preparation of particle-reinforced mullite composite ceramic materials using kaolin and IG-017 bio-origin additives, Építőanyag - JSBCM, Vol. 71, No. 4, 114-119. p. https://doi.org/10.14382/epitoanyag-jsbcm.2019.20

[3] Kurovics, E., Shmakova, A., Kanev, B. and Gömze, L. A. (2017) Development ceramic composites based on $\mathrm{Al}_{2} \mathrm{O}_{3}, \mathrm{SiO}_{2}$ and IG-017 additive, IOP Conf. Ser. Mater. Sci. Eng., vol. 175, 012013 https://doi.org/10.1088/1757-899X/175/1/012013

[4] Kurovics, E., Ibrahim, J. F. M., Gömze, L. A. (2020) Influence of compaction times and pressures on rheological properties of kaolin and sawdust powder mixtures, J. Phys. Conf. Ser., vol. 1527, no. 1, 012002 https://doi.org/10.1088/1742-6596/1527/1/012002

[5] Ibrahim, J. F. M., Kurovics, E., Gömze, L. A. (2020) Investigation of the Rheological Properties of Complex Zeolite-Alumina Mixtures, J. Phys. Conf. Ser., vol. 1527, no. 1, 012009 https://doi.org/10.1088/1742-6596/1527/1/012009

[6] Gerezgiher, A. G., Tamási, K., Ibrahim, J. F. M., Kónya, C., Szabó, T. (2020) Thermoplastic corn starch reinforced with pine wood fibre and calcium carbonate precipitate filler, J. Phys. Conf. Ser., vol. 1527, no. 1, 012042 https://doi.org/10.1088/1742-6596/1527/1/012042

[7] Kotova, O. B., Razmyslov, I. N., Ibrahim, J. F. M., Shushkov, D. A. (2020) Mineral composition of bauxite residue and their surface for innovation materials, Építőanyag - JSBCM, vol. 72, no. 4, pp. 135-139, https://doi.org/10.14382/epitoanyag-jsbcm.2020.22

[8] Tihtih, M., Ibrahim, J. F. M., Kurovics, E. Abdelfattah, M. (2020) Study on the effect of Bi dopant on the structural and optical properties of BaTiO 3 nanoceramics synthesized via sol-gel method, J. Phys. Conf. Ser., vol. 1527, p. 012043, https://doi.org/10.1088/1742-6596/1527/1/012043

[9] Kurovics, E., Gömze, L. A., Ibrahim, J. F. M., Gömze, L. N. (2019) Effect of composition and heat treatment on porosity and microstructures of technical ceramics made from kaolin and IG-017 additive, IOP Conf. Ser. Mater. Sci. Eng., vol. 613, no. 1, 012025 https://doi.org/10.1088/1757-899X/613/1/012025

[10] Tihtih, M., Ponaryadov, A. A., Ibrahim, J.-E. F. M., Kurovics, E., KOTOVA, E. L., Gömze, L. A. (2020) Effect of temperature on the structural properties of barium titanate nanopowders synthesis via sol-gel process, Építőanyag - JSBCM, vol. 72, no. 5, pp. 165-168, https://doi.org/10.14382/epitoanyag-jsbcm.2020.27 
[11] Kurovics, E., Ibrahim, J. F. M., Tihtih, M., Udvardi, B., Nuilek, K., Gömze, L. A., (2020) Examination of mullite ceramic specimens made by conventional casting method from kaolin and sawdust, J. Phys. Conf. Ser., vol. 1527, p. 012034, https://doi.org/10.1088/1742-6596/1527/1/012034

[12] Ibrahim, J.-E. F. M. et al., (2020) Effect of composition and sintering temperature on thermal properties of Zeolite-Alumina Composite Materials, Építőanyag - JSBCM, vol. 72, no. 4, pp. 131-134, https://doi.org/10.14382/epitoanyag-jsbcm.2020.21

[13] Abdelfattah, M., Kocserha, I., Géber, R., Tihtih, M., Móricz, F., (2020) Evaluating the properties and mineral phases of the expanded clay aggregates with the bentonite additive material, J. Phys. Conf. Ser., vol. 1527, p. 012030, https://doi.org/10.1088/1742-6596/1527/1/012030

[14] Ibrahim, J. F. M., et al., (2020) Preparation and Investigation of AluminaZeolite Composite Materials, J. Phys. Conf. Ser., vol. 1527, no. 1, https://doi.org/10.1088/1742-6596/1527/1/012029

[15] Kurovics, E. et al., (2020) Characterization of phase transformation and thermal behavior of Sedlecky Kaolin, Építőanyag - JSBCM, vol. 72, no. 4, pp. 144-147, https://doi.org/10.14382/epitoanyag-jsbcm.2020.24

[15] Ponaryadov, A. V., Kotova, O. B., Tihtih, M., Sun, S., (2020) Natural titanium dioxide nanotubes, Építőanyag - JSBCM, vol. 72, no. 5, pp. 152 155, https://doi.org/10.14382/epitoanyag-jsbcm.2020.25

[16] Ibrahim, J.-E. F. M., Mergen, A., Parlak, U., Tihtih, M., Gömze, L. A., (2021) Synthesis and Characterization of iron-doped $\mathrm{GdMnO}_{3}$ multiferroic ceramics, Építőanyag - JSBCM, vol. 73, no. 1, pp. 24-27, https://doi.org/10.14382/epitoanyag-jsbcm.2021.5

[17] Khirade, P. P., Shinde, A. B., Raut, A. V., Birajdar, S. D., Jadhav, K. M., (2016) Investigations on the synthesis, structural and microstructural characterizations of $\mathrm{Ba1}-\mathrm{xSrxZrO}$ nanoceramics, Ferroelectrics, vol. 504, no. 1, pp. 216-229, https://doi.org/10.1080/00150193.2016.1241633

[18] Viviani, M., Buscaglia, M. T., Nanni, P., Parodi, R., Gemme, G., Dacca, A. (1999) XPS investigation of surface properties of $\mathrm{Ba}_{(1-x)} \mathrm{Sr}_{x} \mathrm{TiO}_{3}$ powders prepared by low temperature aqueous synthesis, J. Eur. Ceram. Soc., vol. 19, no. 6-7, pp. 1047-1051, Jun. 1999,

https://doi.org/10.1016/S0955-2219(98)00371-9

[19] Hong, K. S. et al., (2015) Structural characteristics and chemical bonding states with temperature in barium titanate nanopowders prepared by using the solvothermal method, Curr. Appl. Phys., vol. 15, no. 11, pp. 1377-1383, https://doi.org/10.1016/j.cap.2015.06.028

[20] Yadav, A. K., Gautam, C. R., Mishra, A. (2014) Mechanical and dielectric behaviors of perovskite $(\mathrm{Ba}, \mathrm{Sr}) \mathrm{TiO}_{3}$ borosilicate glass ceramics, J. Adv. Ceram., vol. 3, no. 2, pp. 137-146, https://doi.org/10.1007/s40145-014-0104-2

[21] Ibrahim, J. F. M., Mergen, A., Sahin, E. İ., Basheer, H. S., (2017) The effect of europium doping on the structural and magnetic properties of $\mathrm{GdMnO}_{3}$ multiferroic ceramics, Adv. Ceram. Prog., vol.3, no.4, p.1

[22] Ibrahim, J. F. M., Mergen, A., Parlak, U., Kurovics, E. (2019) The Influence of $\mathrm{Cr}$ doping on the Structural and Magnetic Properties of HoMnO3 Multiferroic Ceramics, IOP Conf. Ser. Mater. Sci. Eng., vol. 613, no. 1, https://doi.org/10.1088/1757-899X/613/1/012009

[23] Rani, A., Kolte, J., Gopalan, P. (2018) Structural, electrical, magnetic and magnetoelectric properties of Co-doped $\mathrm{BaTiO}_{3}$ multiferroic ceramics, Ceram. Int., vol. 44, no. 14, pp. 16703-16711, Oct. 2018, https://doi.org/10.1016/j.ceramint.2018.06.098

[24] Van Der Veer, E., Acuautla, M., Noheda, B. (2020) Ferroelectric PbZr 1-x Ti x O 3 by ethylene glycol-based chemical solution synthesis,

[25] Huang, S. T., Lee, W. W., Chang, J. L., Huang, W. S., Chou, S. Y., Chen, C. C. (2014) Hydrothermal synthesis of $\mathrm{SrTiO} 3$ nanocubes: Characterization, photocatalytic activities, and degradation pathway, J. Taiwan Inst. Chem. Eng., vol. 45, no. 4, pp. 1927-1936, Jul. 2014, https://doi.org/10.1016/j.jtice.2014.02.003

[26] Rosa Silva, E., Curi, M., Furtado, J. G., Ferraz, H. C., Secchi, A. R. (2019) The effect of calcination atmosphere on structural properties of Y-doped $\mathrm{SrTiO}_{3}$ perovskite anode for SOFC prepared by solid-state reaction, Ceram. Int., vol. 45, no. 8, pp. 9761-9770, Jun. 2019, https://doi.org/10.1016/j.ceramint.2019.02.011
[27] Khirade, P. P., Birajdar, S. D., Raut, A. V., Jadhav, K. M. (2016) Effect of $\mathrm{Fe}$ - substitution on phase transformation, optical, electrical and dielectrical properties of $\mathrm{BaTiO}_{3}$ nanoceramics synthesized by sol-gel auto combustion method, J. Electroceramics, vol. 37, no. 1-4, pp. 110-120, https://doi.org/10.1007/s10832-016-0044-z

[28] Choi, G., Choi, A. H., Evans, L. A., Akyol, S., Ben-Nissan, B. (2020) A review: Recent advances in sol-gel-derived hydroxyapatite nanocoatings for clinical applications, J. Am. Ceram. Soc., vol. 103, no. 10, pp. 54425453, Sep. 2020, https://doi.org/10.1111/jace.17118

[29] Tihtih, M., Limame, K., Ababou, Y., Sayouri, S., Ibrahim, J.-E. F. M. (2019) Sol-gel synthesis and structural characterization of Fe doped barium titanate nanoceramics, Építőanyag - JSBCM , vol. 71, no. 6, pp. 190-193, https://doi.org/10.14382/epitoanyag-jsbcm.2019.33

[30] Mohammadi, M. R., Fray, D. J. (2011) Sol-gel derived nanocrystalline and mesoporous barium strontium titanate prepared at room temperature, Particuology, vol. 9, no. 3, pp. 235-242, https://doi.org/10.1016/j.partic.2010.08.012

[31] Bujakiewicz-Koronska, R., Vasylechko, L., Markiewicz, E., Nalecz, D. M., Kalvane, A. (2017) X-ray and dielectric characterization of Co doped tetragonal $\mathrm{BaTiO}_{3}$ ceramics, Phase Transitions, vol. 90, no. 1, pp. 78-85, Jan. 2017, https://doi.org/10.1080/01411594.2016.1252978

[32] Phan, T. L. et al., (2015) Local geometric and electronic structures and origin of magnetism in Co-doped BaTiO3 multiferroics, J. Appl. Phys., vol. 117, no. 17, p. 17D904, May 2015, https://doi.org/10.1063/1.4907182

[33] Nath, D., Singh, F., Das, R. (2020) X-ray diffraction analysis by WilliamsonHall, Halder-Wagner and size-strain plot methods of CdSe nanoparticlesa comparative study, Mater. Chem. Phys., vol. 239, p. 122021, Jan. 2020, https://doi.org/10.1016/j.matchemphys.2019.122021

[34] Hall, W. H. (1949) X-ray line broadening in metals, Proceedings of the Physical Society.Section A, vol. 62, no. 11. pp. 741-743, Nov. 01, 1949, https://doi.org/10.1088/0370-1298/62/11/110

[35] Woldu, T., Raneesh, B., Sreekanth, P., Ramana Reddy, M. V., Philip, R., Kalarikkal, N. (2015) Size dependent nonlinear optical absorption in $\mathrm{BaTiO}_{3}$ nanoparticles, Chem. Phys. Lett., vol. 625, pp. 58-63, https://doi.org/10.1016/j.cplett.2015.02.020

[36] Chandel, S., Thakur, P., Tomar, M., Gupta, V., Thakur, A. (2017) Investigation of structural, optical, dielectric and magnetic studies of $\mathrm{Mn}$ substituted $\mathrm{BiFeO}_{3}$ multiferroics, Ceram. Int., vol. 43, no. 16, pp. 1375013758, Nov. 2017, https://doi.org/10.1016/j.ceramint.2017.07.088

[37] Priya, A. S., Banu, I. B. S., Geetha, D., Sankar, S. (2019) Investigations of the magnetic and dielectric behaviour of $(\mathrm{Zr}, \mathrm{Cu})$ co-doped $\mathrm{BiFeO}_{3}-$ $\mathrm{BaTiO}_{3}$ composite, Mater. Res. Express, vol. 6, no. 10, p. 106116, Sep. 2019, https://doi.org/10.1088/2053-1591/ab3e86

[38] Krimech, F. Z., Sayouri, S. (2019) Structure and dielectric behavior of Cudoped $\mathrm{BaTiO}_{3}$ ceramics, in Materials Today: Proceedings, 2019, vol. 30, pp. 909-917, https://doi.org/10.1016/j.matpr.2020.04.349

[39] Soni, M., Saleem, M., Bajpai, N., Chouhan, S., Varshney, M. D., Mishra, A. (2019) Structural and optical properties on $\mathrm{Na}$ doped $\mathrm{BaTiO}_{3}$, AIP Conf. Proc., vol. 2100, no. April, 2019, https://doi.org/10.1063/1.5098739

Ref.:

Tihtih, Mohammed - Sevostianova, Irina N. - Kurovics, Emese Sablina, Tatiana Yu. - Kulkov, Sergei N. - Gömze, László A.: Examination of the Influence of Cobalt Substitution on the Properties of Barium Titanate Ceramics Építőanyag - Journal of Silicate Based and Composite Materials, Vol. 73, No. 4 (2021), 160-165. p. https://doi.org/10.14382/epitoanyag-jsbcm.2021.24 